\title{
EDITORIAL
}

\section{DEL STUDIUM GENERALE DEL SIGLO XII-XIII A LA MOVILIDAD ESTUDIANTIL DEL SIGLO XX- XXI: Cuando el saber rompe las distancias}

Nos encontramos en una época de madurez en cuanto a la movilidad de estudiantes y profesores por el mundo, el intercambio de saberes se ha dado en todas las formas posibles y, más aún, hoy en día con las nuevas generaciones de las tecnologías de la información y la comunicación. Las asociaciones en torno a una temática se cuentan por centenas y los desplazamientos, para permanecer un período más o menos largo en un lugar, por millones. Deberíamos estar orgullosos de lo alcanzado hasta ahora por la importancia y el alcance de nuestros proyectos, dado que esta es una iniciativa que tiene casi nueve siglos. Así funcionaron los studium generale, verdaderos centros de difusión del saber en la plena Edad Media donde su objetivo primordial era la difusión y el intercambio del conocimiento.

Recordemos que es en el siglo XII cuando se empieza a estructurar y crear el verdadero pilar del modelo actual de universidad. Antes de adentrarnos en su organización, haremos un alto en el origen de la palabra. Su origen latino significaba corporación, razón por la cual vino a utilizarse para designar un gremio, de tal forma que se convirtió en el distintivo que la diferenciaría de las demás formaciones: su organización como corporación a la manera de gremio en lo que se dio en llamar: "Studium Generale", que es donde se cursaban los estudios superiores: el trívium y el cuadrivium.

El florecimiento de este tipo de escuelas sigue un lento pero seguro proceso. Hay testimonios en los que se nos informa del tiempo pasado en la formación. Se sabe, por el beato Jordán, que el fundador de la orden de los predicadores, Santo Domingo de Guzmán consagró diez años de su vida (desde los catorce hasta los veinticuatro) a su formación científica, conocida con el nombre de "artes liberales" las cuales una vez adquiridas se completaban con el aprendizaje de la teología. A este tipo de centros se acudía para capacitarse para el desempeño de altos cargos, lo cual podía ser observado por la función ocupada por quien pasó por allí, o por las declaraciones sobre conocimientos de palabras complejas, sabiendo el significado de ellas.

Podemos afirmar, por testimonios que fechan el nacimiento de estos centros, que hubo una gran preocupación de difundir el saber o ir en su búsqueda a partir del último tercio del siglo XII (hacia 1177-1185) y hasta bien entrada la segunda mitad del siglo XIII. Llegando su apogeo y difusión científica con el trío: Maimonides-Alfonso X-Averroes. 
En el caso de España, los cronistas de Alfonso VIII coinciden en decir que "llamó a muchos maestros y los congregó en Palencia para que allí enseñaran sus conocimientos. Hasta entonces la transmisión del saber se hacía a través de un maestro versus sus discípulos, siendo difícil que un alumno pudiera absorber y cotejar un conocimiento desde la opinión de varios especialistas. Se puede decir pues que de una colaboración entre iglesia y monarquía, tanto por el interés común como por el apoyo económico dedicado (tercias eclesiásticas y rentas reales), surge no solo el sistema de enseñanza superior, sino también el espíritu y tendencia actual de desplazarse en busca de ampliar y perfeccionar sus conocimientos. En su momento, este espíritu fue debido a la exaltación del sentimiento patrio de los hispanos molestos por la creciente invasión de extranjeros en las profesiones liberales, en la alta administración y en el clero.

Se dio la circunstancia de que en 1177, en el cerco de Cuenca, el que fuera creador de la Orden de Santiago, don Pedro Fernández, propuso, junto a otros magnates y prelados, la creación de una escuela en Uclés en la que los hijos de los caballeros estudiasen las artes liberales y en 1185, aprovechando la pascua, el rey apoyaba el estudio general de Palencia donde en esa época no se dudaba en resaltar tal estudio como uno de los más florecientes no solo por el número de facultades, sino por la calidad de profesores y concurrencia de alumnos: (Adefonsus) convocavit ut sapientiae disciplina a regno suo nunquam abaset et magistros ómnium facultatum Palentiae congregavit, quivus et magna stipendia est largitus, ut omni studium cupenti, quasi manna aliquando in os influeret sapienta cujuslibet facultatis. Tales hechos están reflejados en el Chronicon mundi del Tudense de 1236 y el Rerum in Hispania gestarum de Rodrigo Jiménez de Rada de 1243 , dos de las obras referentes que narran la historia de la época.

Habiendo dicho anteriormente que se trataba de un consorcio EstadoIglesia, al rey Alfonso VIII viene a asociarse un obispo llamado Arderico, o viceversa, ya que este nombre está vinculado a toda empresa cultural de la época.

¿Pero, qué se enseñaba en aquella época? Hemos hablado de dos tipos de enseñanza: artes liberales y teología. La primera, las artes liberales, era un conjunto de disciplinas que a lo largo de los siglos se fueron formando en torno a dos áreas: el trivium y el cuadrivium, una y otra conformadas por contenidos en torno a las letras y las ciencias griegas. Las tres vías consistían en la gramática, la retórica y la lógica o dialéctica: hablar-escribir, explicar-disertar, argumentar-debatir. Las cuatro vías se basaban en la aritmética, la geografía, la astronomía y la música.

Es cierto que estas enseñanzas ya estaban consolidadas en épocas romanas y para este imperio eran la base y fundamento de su enseñanza, pero en este periodo había una diferencia esencial ya que no se estudiaban las artes por las artes, sino que eran la base para las grandes profesiones, $\mathrm{o}$, más bien, desde nuestro punto de vista, la base de una formación, que permitía a quien la seguía (una especie de "ingeniero" "genio" o "Ingenioso"), 
ejercer cualquiera de esas grandes profesiones. Si para estos tres términos aceptamos su origen etimológico:

El titulo llamado "bachiller" ya existía en esa época cuyo origen proviene de bacillarius, por el bastón que llevaban aunque muy pronto se le dio en llamar bachalaurei, mencionando la corona (laurea) que se imponía a quienes resolvían los ejercicios, de perlas según unos, de bayas según otros (bacca-ae) encontrando en los diccionarios indistintamente baccatus-a-um (adornado de perlas) y bacialis-e lo que lleva bayas; pudiendo también interpretar el origen bacca del ramo de oliva cuyo árbol se dedica a Minerva. Este detalle, ya sean bayas ya perlas, ya olivo, nos hace pensar en una evaluación continua.

Dentro de los maestros cabe destacar la figura del ya mencionado maestrescuela (o canciller o cancelario), quien era el verdadero jefe de estudios del centro encargándose de contratar a los profesores, controlar los libros y trabajos de estos y sirviendo de enlace con los estudiantes, otorgando también los grados o examinando a los aspirantes a profesor. Por otra parte, hay un mayoral o rector quien se encarga del poder ejecutivo del centro y del control del estado y originalidad de los libros bajo custodia del estacionario. Este, especie de librero o bibliotecario, era el encargado del préstamo o venta de los libros bajo custodia del rector quien le indica la comisión que debe llevarse. Por otra parte, está el bedel quien cuida de anunciar la salida de nuevos libros, el lugar de los exámenes, o los días de fiesta.

Sobre el modo de enseñar, existen indicaciones que nos hacen ver que la enseñanza se transmite a través de la lectura y que se les aconseja a los profesores el ser leales a ella y no dejar sin acabar un libro ya empezado. Se puede hacer hincapié en la lectura, que no el dictado de lo leído. Podemos pues pensar que se trata de una lectura comentada, especie de filosofía de la materia: leer, comparar, comentar y cotejar los problemas con otras lecturas u otros temas. La ciencia no se enseña directamente y en sí misma, sino mediante la explicación de los libros de autores reconocidos y que gozaban de autoridad. No se daba una materia, se leía, y no se seguía una materia se oía.

Este número que aquí presentamos es otro indicio del intercambio de conocimientos y saberes producto de la iniciativa del studium generale del siglo XII-XIII y esperamos que los lectores especializados encuentren en él un referente académico y un espacio de discusión e intercambio de ideas.

Luis Fernando Martínez Arconada

ENIT Francia

Comité Editorial

Adriana Patricia Gallego

Universidad Distrital Francisco José de Caldas

Editora 


\section{GENERALE STUDIUM CENTURY OF XII- XIII A STUDENT MOBILITY XX -XXI CENTURY: When knowledge breaks the distances}

We are in an age of maturity in terms of the mobility of students and teachers around the world, sharing of knowledge has been in every way possible and even more today with the new generation of information technology and communication. Associations around a theme in the hundreds and displacement, to remain a more or less long in one place, by the millions. We should be proud of what has been achieved so far by the importance and scope of our projects, since this is an initiative that has almost nine centuries. So ran the Studium Generale, real centers of dissemination of knowledge in the Middle Ages where its primary purpose was the dissemination and exchange of knowledge.

Recall that in the twelfth century is when you start to structure and create the real pillar of the current model of university. Before getting into your organization, we will stop at the origin of the word. Its origin, Latin meant corporation, which is why he came to be used to designate a guild, so that became the hallmark that differentiate it from other formations: the organization as a corporation in the manner of union in what became to call: "Studium Generale", which is where higher education were enrolled : the trivium and the quadrivium .

The flowering of these schools is a slow but sure process. There is evidence on which we are informed of the time spent in training. It is known, by Blessed Jordan, the founder of the Order of Preachers, Santo Domingo de Guzman devoted ten years of his life (from fourteen to twenty-four) of their scientific, known by the name of "liberal arts" which once acquired were supplemented by learning theology. This kind of went for training centers for senior performance, which could be observed by the role occupied by who happened by, or by statements on knowledge of complex words, knowing the meaning of them.

We can say, for evidence dating the birth of these centers, there was a great concern to spread the know or go search from the last third of the twelfth century (circa 1177-1185) and well into the second half of the century XIII. Reaching its peak and scientific dissemination with the trio: Maimonides -Alfonso X - Averroes.

In the case of Spain, Alfonso VIII chroniclers agree in saying that "called many teachers and brought in Palencia to teach their knowledge there. Until then the transmission of knowledge is made through a teacher versus his disciples, making it difficult for a student could absorb and collate knowledge from the opinion of some experts. It can be said then, that a partnership between church and monarchy, both in the common interest as dedicated financial support (tercias ecclesiastical and royal revenues), arises not only higher education system, but also the spirit and 
trend of maneuvering in looking to expand and improve their knowledge . At the time, this spirit was due to the exaltation of patriotic sentiment of Hispanics upset by the growing invasion of foreigners in the professions, in senior management and in the clergy.

Was given the fact that in 1177, at the siege of Cuenca, former creator of the Order of Santiago, Don Pedro Fernandez, proposed, along with other magnates and prelates, the creation of a school in Uclés in which children of knights estudiasen the liberal arts and in 1185, taking advantage of the Passover, the king supported the General Study of Palencia where at that time not hesitate to highlight such a study as one of the most flourishing not only by the number of powers, but by teacher quality and student attendance (Adefonsus) convocavit sapientiae ut nunquam discipline abaset et regno suo facultatum Palentiae magistros congregavit omnium, et magna stipendia quivus largitus est, ut omni cupenti studium, quasi manna Sapienta aliquando in cujuslibet Facultatis influeret you. These facts are reflected in the Chronicon mundi Tudense of 1236 and the Rerum in Hispania Gestarum Rodrigo Jimenez de Rada, 1243 two related works that tell the story of the time.

Having said earlier that it was a church-state consortium, to King Alfonso VIII comes to associate a bishop named Arderico, or vice versa, as this name is linked to cultural enterprise all the time.

But what was taught in that time?

We talked about two types of education : liberal arts and theology. The first, the liberal arts, was a set of disciplines that over the centuries were formed around two areas: the trivium and the quadrivium, over and over made up content around the Greek letters and sciences. The three-way consisted of grammar, rhetoric and logic or dialectic : talk - write, explain, expound, argue, discuss. The four tracks were based on arithmetic, geography, astronomy and music.

It is true that these teachings were already consolidated in Roman times under whose empire was the basis and foundation of his teaching, but in this period there was an essential difference and not learned the arts for the arts, but were the basis for large professions, or , rather, from my point of view, the training base, which allowed who was ( a kind of "engineer" "genius" and "ingenious "), to exercise any of these great professions. If these three terms to accept its etymological origin.

The title called "bachelor " already existed at that time having origins in bacillarius, carrying the baton but it soon came to be called bachalaurei, mentioning the crown (laurea) to be imposed on those who solved the exercises, pearls according to some, as other berry (bacca -ae) found in dictionaries either baccatus - a-um (decorated with pearls) and bacialis leading -e berries, may also interpret the origin of the olive branch bacca Arboló which is dedicated Minerva. This detail, whether berries and pearls, olive and makes us think of a continuous evaluation. 
Within teachers included the aforementioned figure schoolmaster (or chancellor or cancelario ), who was the true center headteacher charge of hiring teachers, examine the books and works of these and liaising with students, also giving grades or examining aspiring teacher. On the other hand there is a mayoral or rector who is in charge of the executive branch of the central and state control and originality of the books stationary custody. This, kind of bookseller or librarian was in charge of the loan or sale of books rector custody who tells the committee that should be. On the other hand, is the janitor who cares to announce the release of new books, the place of examination, or the holidays .

On how to teach, there are indications that make us see that teaching is transmitted through reading and which advises teachers to be loyal to it and not leave a book unfinished already begun . It may emphasize reading, not the dictation of the reading. We therefore think that it is a commented reading, sort of philosophy of matter: read, compare, discuss and compare with other reading problems or other issues. Science is not taught directly and in itself, but by explaining the known authors and books who enjoyed authority. Not he a subject, was read, and was a subject not heard.

This issue presented here, is another indication of the exchange of knowledge and product knowledge initiative Studium Generale XII-XIII century and what specialized hope readers find it an academic reference and a space for discussion and exchange of ideas.

Luis Fernando Martínez Arconada ENIT France Editorial Committe

Adriana Patricia Gallego 